\title{
A Review on the Customer Role in Smart Service Co-Creation
}

\author{
Marleen Voss \\ Ruhr-Universität Bochum \\ marleen.voss@,isse.rub.de \\ Martin Ebel \\ Ruhr-Universität Bochum \\ martin.ebel@isse.rub.de
}

\author{
Dennis Drenhaus \\ Ruhr-Universität Bochum \\ Thomas Marus \\ Ruhr-Universität Bochum
}

\begin{abstract}
In the course of digital servitization and the introduction of smart services, the provider-customer relationship in manufacturing industries is changing. The cooperation between providers and customers, which is also referred to as co-creation in research, can have a positive impact on the value creation of both parties in the various development phases of smart service. Co-creation is understood as a two-way communication in which providers and customers can exchange their resources, for example in the form of knowledge and skills. However, so far research has focused on the role of the provider in this constellation. Through a systematic literature review, this article examines the role of customers within industrial smart services. Four core areas could be identified within co-creation. These are discussed in the context of existing paradoxes and it is shown that the customer perspective should be given equal consideration in future research.
\end{abstract}

\section{Introduction}

SJÖDIN ET AL. consider that the competitiveness of companies in B2B industries depends largely on the extent to which digital service offerings are made available [1]. The transformation of companies from purely product-centric to service-centric providers is hereby driven by the advancing digitization [2]. The so called digital servitization can be defined as, "[...] the transformation in processes, capabilities, and offerings within industrial firms and their associate ecosystems to progressively create, deliver, and capture increased service value arising from a broad range of enabling digital technologies" [1, p.479].

Accordingly, companies are faced with the challenge of rethinking their previous understanding of a business model and striving for innovation in this regard [3]. In the context of digital servitization, technologies offer many opportunities to develop innovative business models [4]. These include "[...] intelligent, digitally networked systems that enable machines, humans, systems, products and logistics to communicate and cooperate with each other in real time" [5, p.2]. This extensive digital networking is made possible by the Internet of Things which ensures the creation of huge amounts of data, which in turn enable companies to offer innovative services based on this information [6]. Such are known as data-driven service [7, 8], smart service [9, 10], or advanced service $[11,12]$. Further we will continue to use the term smart service in this study.

Smart services describe emerging offerings that arise in multi-actor settings [9] and for whose success existing business logics and development approaches are challenged $[1,13,14]$. According to GRANDINETTI ET AL., to create enhanced customer benefits with smart services, it is crucial to have access to the customer and data. The offering of smart services hereby leads to transformational changes in present supplier-customer relationships [6].

In theory, customer orientation and integration are emphasized within named smart service innovation [15]. The interaction between the customers and the providers of smart services can be attributed as essential $[1,16]$. Empirical work, however, figured out that the customer often plays a secondary role in real world projects by mainly sharing feedback and information [9]. It is important to find out how such collaboration looks like and what role the customer really plays [17]. Not least because a main challenge in implementing smart services is to involve customers and exploiting data that they are not always willing to share [14].

So far, the focus in research has mostly been on the providers and less on the customers $[15,18,19]$. In order to generate further insights, the following research question is stated: What roles do customers play in smart services within the manufacturing industry? To tackle this question, we decided on a systematic literature review that focuses on analyzing the role of the customer within smart services.

The paper is structured as follows. First, we will explain the basic terminology of smart service and cocreation. Further, we explain the methodological 
approach of our review. In the following, the results in form of four identified categories will be presented. These will be discussed afterwards.

\section{Related Works}

\subsection{Smart Service}

WÜNDERLICH ET AL. refer to technology-based services that involve a high level of active participation by providers and customers (e.g. remote diagnosis and repair of equipment) as "smart interactive services" [20]. Despite this further generic view, we follow DREYER ET AL. [19] who define smart service as "individual, highly dynamic and qualitybased service solutions that are convenient for the customer, realized with field intelligence and analyses of technology, environment and social context data (partially in real-time)" [19, p.57]. Further they consider that smart services can be divided into the life phases of design, transition, operation and improvement, as well as a strategic component. Such classification may also be helpful to examine the role of the customer and is thereby used within our analysis.

Smart services are created in the context of smart service systems that allow continuous data collection and analysis based on resources for sensing and computing within networked people and things to offer the opportunity of wireless communication and value co-creation $[10,21]$. Smart services are strategically important in both B2B and B2C [21]. However, since these two approaches differ from each other in their environment, a differentiated view is necessary [22]. In our article we focus on the B2B industry.

BEVERUNGEN ET AL. [10] consider that smart products play a mediating role between the providers and the customers. Furthermore, they consider the interaction between different actors, objects or organizations as an important basis for smart services.

Within smart services, not only the digitized environment, also the nature of the provider-customer relationship changes [13]. KAMALALDIN ET AL. further emphasize the important factor of interaction between providers and customers [15]. Due to the changes in the provider-customer relationship, SJÖDIN ET AL. [1] also believe that providers and customers must be responsible for many new and more active roles. In terms of the life cycle of smart services, providers and customers interact closely [10] and share their knowledge and important information for the purpose of possible improvement opportunities [19]. The interaction can take place in different phases and differ in nature. A distinction can be made between direct interactions (for example, feedback by customers) and indirect interactions (for example, data release by customers) [19].

The collaborative and close cooperation with other actors, and significantly also with the customer, for the development and creation of new value propositions, but also for the creation of values, is understood in academia as co-creation [23].

\subsection{Different Lenses on Co-Creation}

In the past, customers were often offered products or services for sale which the providers largely developed themselves. The co-creation approach changes this relationship between providers and customers in that customers can exert more influence on the value of the product or service by interacting with the providers [23]. In the following sections, different approaches of understanding co-creation are presented.

One of the first research approaches dealing with co-creation was developed by PRAHALAD AND RAMASWAMY [24, 25]. They see customers as an important component in the creation of value within a company. This is because the interaction between the customers and the offering companies means that the customers' experiences can make a significant contribution to value creation. Companies should move away from their product-centric view and place more emphasis on customer experience. Further, companies are meant to have the duty to rethink and to involve customers in the value creation process. By interacting with them, the company is able to create added value for customers [24]. In this regard, companies are able to create competitive advantages over companies that operate differently [25].

Another possibility of co-creation describes the so-called "customer co-creation", which can be used to develop innovative products and services. Customer co-creation is defined as a communication process between service providers and customers that aims to better understand customer needs [26]. In the context of innovative service development, we can also speak of collaboration, which also uses the interaction of providers and customers to be able to develop innovative services [27]. Companies can design new ideas through this collaborative cooperation by considering customers as an important external resource [27].

Moreover, co-creation is often considered in research within the framework of the servicedominant logic (SDL). It is considered "foundational to service science and to the study of value-creation in service systems" [18, p. 146]. It does not view service providers and customers as two opposing parties, but 
focuses on the interaction between them. By exchanging their respective resources in the form of skills and knowledge, the providers and customers can jointly create value for themselves or other beneficiaries [28]. SDL is based on the "value-in-use" idea and thus contrasts with the traditional view, which is called "goods-dominant logic" and is based on the "value-in-exchange" idea [29].

\subsection{Drawbacks of Co-Creation}

Co-creation does not always have a positive effect on development of services and also entails risks and negative aspects [1, p.480]. In "The dark side of customer co-creation: exploring the consequences of failed co-created services" written by HEIDENREICH ET AL. the negative sides of co-creation in the development and provision of services are highlighted [30]. In principle, service failures can never be completely ruled out. However, due to the high level of customer participation and the effort involved, customer expectations are at a high level. For this reason, a service error can trigger a correspondingly higher level of dissatisfaction on the customer side. HEIDENREICH ET AL. confirm the hypothesis that "in the case of service failure, customers using services high on co-creation will be less satisfied than customers using the same service low on co-creation." [30, p.281]. According to this hypothesis, customers with a high co-creation rate and a successful service are more satisfied than customers with a low cocreation rate. However, a service failure conversely leads to these customers being less satisfied with the service than customers with lower co-creation shares. In the case of a service error with a high co-creation share, however, customers feel a certain responsibility to rectify this error. In contrast, customers who were hardly involved in the provision try to shift responsibility to the service providers and expect the error to be rectified by the respective company. SJÖDIN ET AL. [1] also see the risks in co-creation, that the relationship between the actors involved can be negatively affected and the role assignments of the actors can lead to conflicts.

As explained at the beginning, it is not possible to determine a universally valid definition of co-creation, since there are different ways of looking at this topic depending on the authors. Nevertheless, commonalities can be identified by means of the cocreation approaches described above. At their core, they all describe a type of joint interaction between different actors. An important aspect within this interaction is also the exchange of knowledge and skills, which makes it possible to generate the value defined in advance.
The extent to which customers can ultimately be involved in the value creation process is also interpreted in different ways. The co-creation approach is used in today's literature for many areas in daily life and serves to describe different actors and their collaborative cooperation [31]. In the context of innovative service and product development, cocreation is increasingly seen as an important approach to optimize the quality of offerings [27, 32]. Customers are expected to play a more important role in this process so that the focus should not only lie on providers. This development is now also increasingly evident in digital servitization and is being researched more and more $[1,11,15,20]$.

\section{Method}

A systematic literature review, following the methodology described by TEMPLIER AND PARÉ [33], will be used to answer the research question. Basically, three main phases can be distinguished in a systematic literature search. These are divided into planning, conducting and reporting. In the planning phase, a research question and a concept should first be created, on the basis of which the research can then be carried out. For our planning phase, we used the framework of VOM BROCKE ET AL. [34] and classified our procedure within their framework.

Our process of systematic literature research can be classified as sequential, based on bibliographic databases, representative and as a keyword search. This becomes visible in Table 1 by means of the fields with a grey background.

Table 1: Literature review planning [34]

\begin{tabular}{|l||l|l|l|}
\hline \multicolumn{1}{|l||}{ Process } & \multicolumn{2}{c|}{ Sequential } & \multicolumn{2}{c|}{ Iterative } \\
\hline \multirow{2}{*}{ Sources } & $\begin{array}{l}\text { Citation } \\
\text { indexing } \\
\text { services }\end{array}$ & $\begin{array}{l}\text { Bibliographic } \\
\text { databases }\end{array}$ & Publications \\
\hline Coverage & $\begin{array}{l}\text { Compre- } \\
\text { hensive }\end{array}$ & $\begin{array}{l}\text { Represen- } \\
\text { tative }\end{array}$ & Seminal works \\
\hline Technique & $\begin{array}{l}\text { Keyword } \\
\text { search }\end{array}$ & $\begin{array}{l}\text { Backward } \\
\text { search }\end{array}$ & $\begin{array}{l}\text { Forward } \\
\text { search }\end{array}$ \\
\hline
\end{tabular}

In the subsequent implementation phase, all relevant research contributions are searched for and selected. Subsequently, these are to be evaluated according to their quality and the most important findings are to be extracted from them in order to be subsequently analyzed as well as synthesized [33].

For better comprehensibility of the systematic literature search, the search process for selecting relevant research articles was documented. The initial focus was on the selection of databases and the subsequent definition of the search algorithm. Due to 
the large number of different databases, it was decided in this systematic literature search to focus on the three large and well-known databases "Scopus", "Web of Science" and "Ebscohost".

Our research procedure is shown in Figure 1. We searched in the databases using the keywords "(smart service* OR advanced service* OR digital servitization*) AND (customer* OR user* OR consumer*)".

The terms above best represent the synonyms and terms used in the context under review. Further additions such as beneficiary did not lead to any further results, which is why it was not integrated.

Our search in the Scopus, Web of Science and Ebscohost databases led to an initial aggregated number of over 2000 contributions (Figure 1).

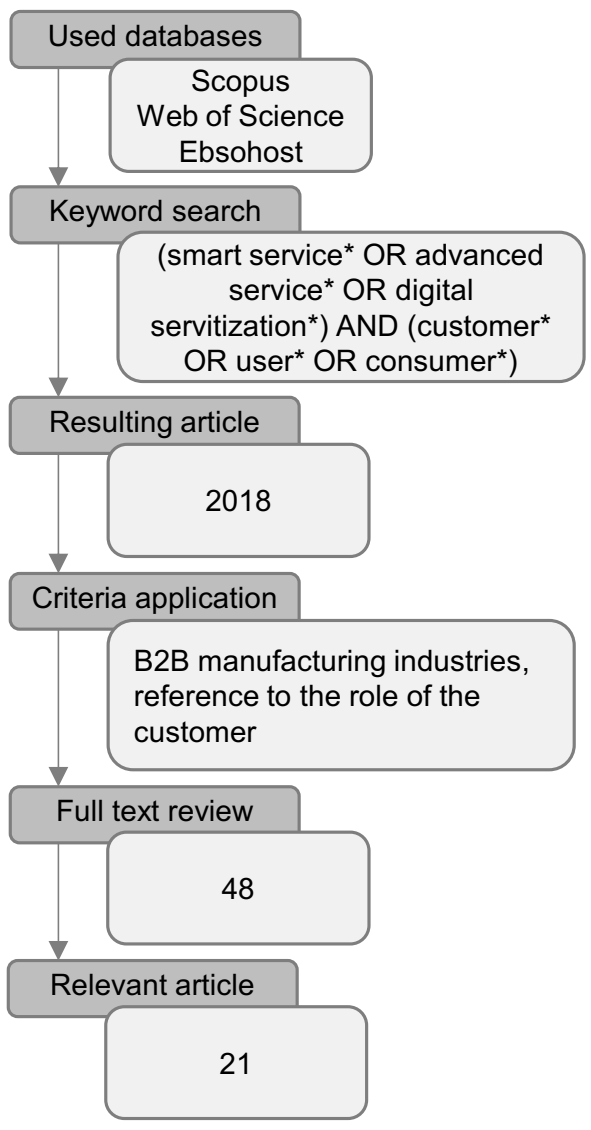

Figure 1: Conducted literature review

We then filtered out duplicates and non-academic sources. In addition, we focused on the B2B manufacturing industries and verified that the articles made references to the role of the customer. Publications on the topic of healthcare, smart cities or smart grid were excluded. This led to 48 publications for full-text analysis. For the full text analysis, we coded the articles using MAXQDA software. We inductively coded respective contents focused on the role of the customer in smart service. We also coded deductively the respective lifecycle phase, based on DREYER ET AL. [19], which was considered in corresponding papers.

Within coding we reviewed to what extent the articles had a focus on the role of the customer. Three asterisk $(* * *)$ mean a very clear and distinct focus on the customers role, one asterisk means that the role of the customer is only superficially described. Papers that did not thematize the role of the customer at all were already removed in the literature search. The result is marked in Table 3 in the Appendix.

After initially coding all segments relevant to our research question, we used the visualization tool of MAXQDA to rearrange and cluster found customer roles visually. We thereby tried to find consensus by discussing the roles and develop superordinate categories. This procedure resulted in the thematic focal points (categories) described in the following chapter.

\section{Results}

It was found that the role of the customer is not clearly defined in the literature on smart services. Nevertheless, it should be noted that the customer played an omnipresent role in the papers examined.

It was noticeable that even if the customer is seen as an important actor in smart service value creation, the subject matter is frequently addressed from the provider's point of view. "The importance of involving customers in the design and delivery of services - that is, co-creating services based on customers' needs instead of on only what providers believe they can offer" [35, p.640] The dedicated customer perspective is only taken by few papers. For example, Story et al., who explicitly addresses the role of the customer as well as the role of the provider [11].

When evaluating and assigning the phases, it is noticeable that a large part of the customer's role is in the design and operations phase. Fewer articles deal with the strategic consideration of the customer's role (Table 3).

Due to the coding procedure we came up with four categories that have been addressed in relation to the role of the customer. Namely these are (1) collaboration, (2) change, (3) integrate and build capabilities, (4) balancing. Further we will give examples and descriptions for each category. 


\subsection{Collaboration}

The first essential point in the analysed articles is the collaboration between the customer and the provider. Collaboration must be thought of in a new form and lived with the customer. Different forms of collaboration became clear in the elaboration. The aggregation of the construct collaboration consists of several sub-categories and thus of different perspectives on collaboration. For us, collaboration in this context means both the establishment of a sustainable and stable relationship and the integration of the customer into the supplier's development and design processes. The customer can act as an informant, user or prosumer, among other things. Prosumer in this context means "[...] that customers will participate in the design of something that they will later consume [...]", so they are producer and consumer [35, p.635].

SJÖDIN ET AL. see a transformation in the nature of the interaction between customer and provider [1]. This is changing from a transactionalbased to a relationship-based collaboration. WÜNDERLICH ET AL. conclude in their paper that "collaboration beliefs (as reflected in willingness to collaborate, perceptions of role clarity, guidance and self-efficacy) positively influence the user's attitudinal and behavioral responses to smart interactive services" [20, p.13].

The exchange of information and data is also an essential part of collaboration in our investigation. The customer, as a user, can also become an informant and creates and evaluates value in use. By sharing information and providing access, the provider gains knowledge about the customer so that the services can be tailored to the client. In addition, the provider can use insights from the data for further development [7].

\subsection{Change}

Another important aspect that emerged from the analysis is the topic of change. This includes aspects such as an open mind, new forms of cooperation, trust and customer orientation.

On the one hand, this means that the customer organisation has to realign and adapt in terms of its processes, culture, mindset and traditions. On the other hand, the provider also needs to understand the culture and habits of the customer and consider how to better tailor the service to the customer [36]. More and more providers see customer involvement as a way to generate new service ideas or to improve and enhance existing services [37]. In order to implement and shape these new forms of cooperation and the changed mindset, building trust between customer and provider is an essential component. Especially with regard to information and data exchange, trust increases the willingness to share and provide it [15].

"The need to become immersed in customer processes is clearly evident, though the extent to which the customer is willing to allow this varies depending, again, on the context and access to decision-makers “ $[17, \mathrm{p} .18]$.

In general, the aspect of change is understood as the willingness to adapt the processes and the way of thinking on the part of both the supplier and the customer. In this context, the adaptation of technologies and the willingness to invest on the part of the customer also play a decisive role.

„In terms of digital technologies in the foundational phase of the relationship, partners are likely to jointly invest in building digital systems for customer operations. For example, companies often described initial efforts to install sensors or to connect a fleet of machines as key enablers of the digital transformation“ $[15$, p.9].

\subsection{Integrate and Build Capabilities}

The third category was the integration, but also the building of capabilities. "Capabilities need to be interactively developed between the customer and the manufacturer" [36, p.1076]. Authors emphasized that both, providers and consumers, must agree on projects and contribute resources and capabilities to develop or provide smart services. "Another aspect stressed by respondents is the importance of sharing risk and reward between provider and customer. Since digital services often involve the provider taking on responsibility for operation of the equipment" $[16$, p.9]. This requires negotiating contracts and demonstrating commitment from the various parties. There is also talk of the need to convince customers. "Establishing platforms to engage customers. All case firms establish various platforms to engage customers and proactively involve customers in the valuecreation process" [37, p.326].

\subsection{Balancing}

In addition to building capabilities, however, some articles also warn of a dependency relationship. Statements on this were summarized in the fourth category under balancing control. Even though only a few authors talk about this, it was included because it reveals important insights about the attitude and role of the customer. The authors noted here that the custo- 
Table 2. Named areas of the customer role in smart service co-creation

\begin{tabular}{|c|c|c|c|c|c|c|c|c|c|c|c|c|c|c|c|c|c|c|c|c|c|}
\hline Authors & 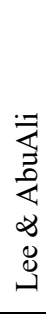 & 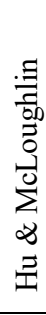 & 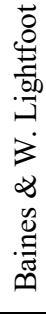 & 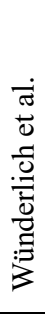 & 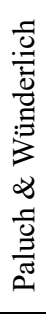 & 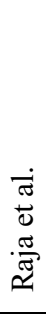 & $\begin{array}{l}\tilde{\pi} \\
\tilde{0} \\
\tilde{0} \\
\frac{0}{0} \\
\tilde{\sigma}\end{array}$ & 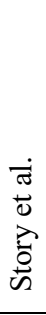 & 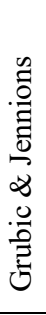 & 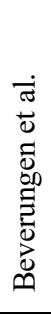 & 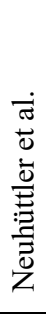 & 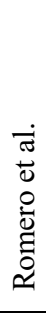 & 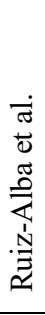 & 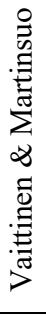 & $\begin{array}{l}\pi \\
0 \\
0 \\
0 \\
0 \\
0 \\
0 \\
0\end{array}$ & 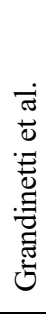 & 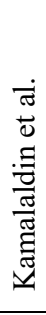 & 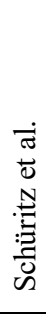 & $\begin{array}{l}\dot{\pi} \\
\text { Uं } \\
\frac{\pi}{\pi} \\
\frac{\pi}{\pi}\end{array}$ & 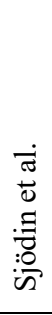 & 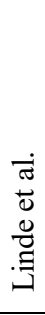 \\
\hline Reference & $\begin{array}{l}\infty \\
m\end{array}$ & $\underline{n}$ & 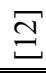 & 尺्ల & ळa & $\Xi$ & $\stackrel{8}{+}$ & $\Xi$ & $\Xi$ & $\Xi$ & I & $\stackrel{\mathscr{m}}{ \pm}$ & 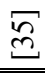 & $\begin{array}{l}\sigma \\
ల \\
\end{array}$ & 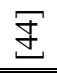 & $\sqrt{6}$ & 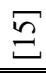 & $\Sigma$ & $\stackrel{5}{ \pm}$ & $\Xi$ & $\stackrel{\sigma}{己}$ \\
\hline Collaboration & & $\mathrm{x}$ & $\mathrm{x}$ & & & $\mathrm{x}$ & $\mathrm{x}$ & $\mathrm{x}$ & $\mathrm{x}$ & $\mathrm{x}$ & $\mathrm{x}$ & $\mathrm{x}$ & $\mathrm{x}$ & $\mathrm{x}$ & $\mathrm{x}$ & $\mathrm{x}$ & $\mathrm{x}$ & $\mathrm{x}$ & $\mathrm{x}$ & $\mathrm{x}$ & $\mathrm{x}$ \\
\hline Change & $\mathrm{x}$ & $\mathrm{x}$ & $\mathrm{x}$ & $\mathrm{x}$ & $\mathrm{x}$ & $\mathrm{x}$ & & $\mathrm{x}$ & & $\mathrm{x}$ & $\mathrm{x}$ & & $\mathrm{x}$ & $\mathrm{x}$ & $\mathrm{x}$ & & $\mathrm{x}$ & $\mathrm{x}$ & & $\mathrm{x}$ & $\mathrm{x}$ \\
\hline $\begin{array}{l}\text { Integrate/ build } \\
\text { capabilities }\end{array}$ & $\mathrm{x}$ & $\mathrm{x}$ & $\mathrm{x}$ & & & $\mathrm{x}$ & $\mathrm{x}$ & $\mathrm{x}$ & $\mathrm{x}$ & & $\mathrm{x}$ & & $\mathrm{x}$ & $\mathrm{x}$ & & & $\mathrm{x}$ & & & $\mathrm{x}$ & $\mathrm{x}$ \\
\hline Balancing & & & & $\mathrm{x}$ & & $\mathrm{x}$ & & $\mathrm{x}$ & & & & & & $\mathrm{x}$ & & & & & & & \\
\hline
\end{tabular}

mer still has to remain capable of making decisions. "Consequently, part of the challenge in offering advanced analytical services is to create solutions which allow others (the customer) to develop analytical insights, while ensuring that the providers obtain only limited knowledge" [17, p.14]. To do this, customers should retain resources and skills, for example in dealing with new technologies, but also in being able to see through and evaluate complex contract structures. "It is, therefore, clear that customers need to balance intimacy, and all the benefits that this brings, with careful consideration of key contractual aspects of these relationships, which can be particularly complex" [11, p.10].

\section{Discussion}

By showing the different roles but also the different understandings of the role of the customer we could give more clarity to the research context of smart service and co-creation as a current research field. Our findings underpin the important role the customer plays, but it is still not clear what this role looks like and how providers should react to it. Literature shows, that the customer is sometimes only seen as a pure informant or an object of consideration, which stands in contrast to the understanding of the SDL.

The state of research on the transformation to a smart service provider shows that the path does not always bring only advantages. It is important to note that although digitization accelerates investment in new technologies and capabilities and the transformation from pure product provider to service provider, it can also have negative effects. In the literature, this is referred to as service or digitization paradoxes. It would be interesting to see whether there are connections between certain roles of the customer and the co-creation practiced and the success or failure of these transformations.

Described disadvantages of co-creation seem to occur especially in standardized services. Particularly in the case of smart services, the literature seems to agree that the involvement of customers in the value creation and development process is indispensable and advantageous. Nevertheless, there is a lack of a more differentiated view of the various roles and an examination of possible factors that can lead to the failure of projects or to a digitalization paradox described above, in which the investments in change do not pay off.

It is often simply postulated that the customer must be integrated and proposed processes assume this collaboration. It would be interesting to examine in future research what advantages the customer has here, or to what extent integration is beneficial or even disadvantageous. Such a view from the customer's point of view is indispensable and research should find a balance in order to see the various stakeholders on an equal footing. So far, there has been a strong focus on the providers. However, customers also have to invest considerable effort in these activities, and it is still unclear how they will be incentivized in addition to more customized solutions.

In this context, balancing intimacy by the customer is pointed out by $[11,17,20,36]$ as a decisive role. However, this is currently addressed in only a few contributions. This topic could also be an overarching point, as it affects many other areas we 
have pointed out. For example, the customer needs to keep his own skills within the company in order to remain capable of making decisions [11]. Also, when it comes to collaboration and acting as an informant, the customer needs to find an appropriate balance between sharing their data and protecting it.

Another research stream is concerned with value co-destruction. Here it concerns the topic that by problems in the collaboration between providers and customers. Examples of this are misinformation, lack of trust, lack of behavior, and lack of ability to deliver ones promises which ultimately leads to value destruction instead of creation. Such factors can take place before or after a collaboration [46].

Further, we were able to plot the overarching phases of the smart service lifecycle named above [19]. The results are highlighted in Table 3, in the Appendix. Nonetheless, we were not able to differentiate in which phases, or even which specific tasks, customers take over as the definitions and descriptions of researched articles was not granular enough. However, the goal of this paper was not to equalize these understandings, but to develop a holistic picture of the described roles of the customer.

Basically, this systematic literature review provides a very good overview for understanding the role of the customer in industrial smart services. As further research, a forward and backward search would be recommended. This would consolidate the scientific validity and, perhaps, reveal additional roles of the customer. Furthermore, the exploration of other industries besides the manufacturing industry could be interesting and provide exciting insights into the view of the customer role in smart service co-creation.

\section{Acknowledgments}

This contribution is part of the projects "Smart Service Retrofits for the Highest Availability of Machinery and Equipment" (retrosmart) and "Development of a Privacy Management System for Personalized Assistance Systems in Production and Service" (PersonA) funded by the German Federal Ministry of Education and Research (grant numbers: 02K16C000 and 02L18B550).

\section{References}

[1] Sjödin, D., V. Parida, M. Kohtamäki, and J. Wincent, "An agile co-creation process for digital servitization: A micro-service innovation approach", Journal of Business Research 112, 2020, pp. 478-491.

[2] Coreynen, W., P. Matthyssens, and W. Van Bockhaven, "Boosting servitization through digitization: Pathways and dynamic resource configurations for manufacturers", Industrial Marketing Management 60, 2017, pp. 42-53.

[3] Sjödin, D., V. Parida, M. Jovanovic, and I. Visnjic, "Value Creation and Value Capture Alignment in Business Model Innovation: A Process View on Outcome-Based Business Models", Journal of Product Innovation Management 37(2), 2020, pp. 158-183.

[4] Beverungen, D., M. Matzner, and C. Janiesch, "Information systems for smart services", Information Systems and e-Business Management 15(4), 2017, pp. 781-787.

[5] Kaltenbach, F., P. Marber, C. Gosemann, T. Bolts, and A. Kuhn, "Smart Services Maturity Level in Germany”, 2018 IEEE International Conference on Engineering, Technology and Innovation (ICE/ITMC), IEEE (2018), 1-7.

[6] Grandinetti, R., M.V. Ciasullo, M. Paiola, and F. Schiavone, "Fourth industrial revolution, digital servitization and relationship quality in Italian B2B manufacturing firms. An exploratory study", The TQM Journal 32(4), 2020, pp. 647-671.

[7] Schüritz, R., B. Wixom, K. Farrell, and G. Satzger, "Value Co-Creation in Data-Driven Services: Towards a Deeper Understanding of the Joint Sphere", ICIS, 2019, pp. 10.

[8] Schüritz, R., S. Seebacher, and R. Dorner, "Capturing Value from Data: Revenue Models for Data-Driven Services", (2017).

[9] Anke, J., J. Poeppelbuss, and R. Alt, "It Takes More than Two to Tango: Identifying Roles and Patterns in Multi-Actor Smart Service Innovation", Schmalenbach Business Review 72(4), 2020, pp. 599634.

[10] Beverungen, D., O. Müller, M. Matzner, J. Mendling, and J. vom Brocke, "Conceptualizing smart service systems”, Electronic Markets 29(1), 2019, pp. 7-18.

[11] Story, V.M., C. Raddats, J. Burton, J. Zolkiewski, and T. Baines, "Capabilities for advanced services: A multi-actor perspective", Industrial Marketing Management 60, 2017, pp. 54-68.

[12] Baines, T., and H. W. Lightfoot, "Servitization of the manufacturing firm: Exploring the operations practices and technologies that deliver advanced services", International Journal of Operations \& Production Management 34(1), 2013, pp. 2-35.

[13] Töytäri, P., T. Turunen, M. Klein, et al., "Overcoming institutional and capability barriers to smart services", Proceedings of the 50th Hawaii International Conference on System Sciences, (2017).

[14] Klein, M.M., S.S. Biehl, and T. Friedli, "Barriers to smart services for manufacturing companies - an exploratory study in the capital goods industry", Journal of Business \& Industrial Marketing 33(6), 2018, pp. 846-856.

[15] Kamalaldin, A., L. Linde, D. Sjödin, and V. Parida, "Transforming provider-customer relationships in digital servitization: A relational view on digitalization", Industrial Marketing Management 89, 2020, pp. 306-325. 
[16] Linde, L., J. Frishammar, and V. Parida, "Revenue Models for Digital Servitization: A Value Capture Framework for Designing, Developing, and Scaling Digital Services", IEEE Transactions on Engineering Management, 2021, pp. 1-16.

[17] Raja, J.Z., T. Frandsen, and J. Mouritsen, "Exploring the managerial dilemmas encountered by advanced analytical equipment providers in developing serviceled growth strategies", International Journal of Production Economics 192, 2017, pp. 120-132.

[18] Gillig, H., and K. Sailer, "User involvement in the innovation process: Development of a framework for e-services", 2012 18th International ICE Conference on Engineering, Technology and Innovation, IEEE (2012), 1-11.

[19] Dreyer, S., D. Olivotti, B. Lebek, and M.H. Breitner, "Focusing the customer through smart services: a literature review", Electronic Markets 29(1), 2019, pp. 55-78.

[20] Wünderlich, N.V., F. v. Wangenheim, and M.J. Bitner, "High Tech and High Touch: A Framework for Understanding User Attitudes and Behaviors Related to Smart Interactive Services", Journal of Service Research 16(1), 2013, pp. 3-20.

[21] Lim, C., and P.P. Maglio, "Data-Driven Understanding of Smart Service Systems Through Text Mining", Service Science 10(2), 2018, pp. 154180.

[22] Wuenderlich, N.V., K. Heinonen, A.L. Ostrom, et al., "'Futurizing' smart service: implications for service researchers and managers", Journal of Services Marketing 29(6/7), 2015, pp. 442-447.

[23] Payne, A.F., K. Storbacka, and P. Frow, "Managing the co-creation of value", Journal of the Academy of Marketing Science 36(1), 2008, pp. 83-96.

[24] Prahalad, C.K., and V. Ramaswamy, "Co-creating unique value with customers", Strategy \& Leadership 32(3), 2004, pp. 4-9.

[25] Prahalad, C.K., and V. Ramaswamy, "Co-creation experiences: The next practice in value creation", Journal of Interactive Marketing 18(3), 2004, pp. 514.

[26] Gustafsson, A., P. Kristensson, and L. Witell, "Customer co-creation in service innovation: a matter of communication?", Journal of Service Management 23(3), 2012, pp. 311-327.

[27] Heirati, N., and V. Siahtiri, "Driving service innovativeness via collaboration with customers and suppliers: Evidence from business-to-business services", Industrial Marketing Management 78, 2019, pp. 6-16.

[28] Vargo, S.L., and R.F. Lusch, "Institutions and axioms: an extension and update of service-dominant logic", Journal of the Academy of Marketing Science 44(1), 2016, pp. 5-23.

[29] Eggert, A., W. Ulaga, P. Frow, and A. Payne, "Conceptualizing and communicating value in business markets: From value in exchange to value in use", Industrial Marketing Management 69, 2018, pp. 80-90.
[30] Heidenreich, S., K. Wittkowski, M. Handrich, and T. Falk, "The dark side of customer co-creation: exploring the consequences of failed co-created services", Journal of the Academy of Marketing Science 43(3), 2015, pp. 279-296.

[31] Galvagno, M., and D. Dalli, "Theory of value cocreation: a systematic literature review", Managing Service Quality 24(6), 2014, pp. 643-683.

[32] Boukhris, A., A. Fritzsche, and K. Möslein, "Cocreation in the Early Stage of Product-service System Development", Procedia CIRP 63, 2017, pp. 27-32.

[33] Templier, M., and G. Paré, "A Framework for Guiding and Evaluating Literature Reviews", Communications of the Association for Information Systems 37, 2015.

[34] vom Brocke, J., A. Simons, K. Riemer, B. Niehaves, R. Plattfaut, and A. Cleven, "Standing on the Shoulders of Giants: Challenges and Recommendations of Literature Search in Information Systems Research", Communications of the Association for Information Systems 37, 2015.

[35] Ruiz-Alba, J.L., A. Soares, M.A. Rodríguez-Molina, and D.M. Frías-Jamilena, "Servitization strategies from customers' perspective: the moderating role of co-creation”, Journal of Business \& Industrial Marketing 34(3), 2019, pp. 628-642.

[36] Vaittinen, E., and M. Martinsuo, "Industrial customers' organizational readiness for new advanced services", Journal of Manufacturing Technology Management 30(7), 2019, pp. 1073-1096.

[37] Hu, Y., and D. McLoughlin, "Creating new market for industrial services in nascent fields", Journal of Services Marketing 26(5), 2012, pp. 322-331.

[38] Lee, J., and M. AbuAli, "Innovative Product Advanced Service Systems (I-PASS): methodology, tools, and applications for dominant service design", The International Journal of Advanced Manufacturing Technology 52(9-12), 2011, pp. 1161-1173.

[39] Paluch, S., and N.V. Wünderlich, "Contrasting risk perceptions of technology-based service innovations in inter-organizational settings", Journal of Business Research 69(7), 2016, pp. 2424-2431.

[40] Salonen, A., O. Saglam, and F. Hacklin, "Servitization as reinforcement, not transformation", Journal of Service Management 28(4), 2017, pp. 662-686.

[41] Grubic, T., and I. Jennions, "Remote monitoring technology and servitised strategies - factors characterising the organisational application", International Journal of Production Research 56(6), 2018, pp. 2133-2149.

[42] Neuhüttler, J., W. Ganz, and D. Spath, “An Integrative Quality Framework for Developing Industrial Smart Services”, Service Science 11(3), 2019, pp. 157-171.

[43] Romero, D., P. Gaiardelli, G. Pezzotta, and S. Cavalieri, "The Impact of Digital Technologies on Services Characteristics: Towards Digital Servitization”, In F. Ameri, K.E. Stecke, G. von Cieminski and D. Kiritsis, eds., Advances in Production Management Systems. Production Management for the Factory of the Future. Springer International Publishing, Cham, 2019, 493-501. 
[44] Boldosova, V., "Telling stories that sell: The role of storytelling and big data analytics in smart service sales”, Industrial Marketing Management 86, 2020, pp. 122-134.

[45] Shah, S.A.A., M.S.S. Jajja, K.A. Chatha, and S. Farooq, "Servitization and supply chain integration:
An empirical analysis", International Journal of Production Economics 229, 2020, pp. 107765.

[46] Järvi, H., A.-K. Kähkönen, and H. Torvinen, "When value co-creation fails: Reasons that lead to value codestruction", Scandinavian Journal of Management 34(1), 2018, pp. 63-77.

\section{Appendix}

Table 3. Examined literature

\begin{tabular}{|c|c|c|c|c|c|c|c|c|c|c|}
\hline 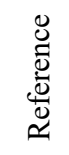 & Author & Year & Title & Outlet & 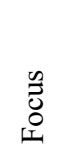 & 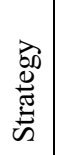 & 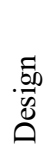 & 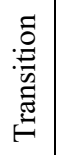 & 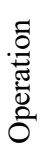 & 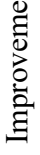 \\
\hline [38] & $\begin{array}{l}\text { Lee } \& \\
\text { AbuAli }\end{array}$ & 2011 & $\begin{array}{l}\text { Innovative Product Advanced Service Systems (I- } \\
\text { PASS): methodology, tools, and applications for } \\
\text { dominant service design }\end{array}$ & $\begin{array}{l}\text { Int J Adv } \\
\text { Manuf } \\
\text { Technol }\end{array}$ & $*$ & & $\mathrm{X}$ & & & \\
\hline [37] & $\begin{array}{l}\mathrm{Hu} \& \\
\text { McLoughlin }\end{array}$ & 2012 & $\begin{array}{l}\text { Creating new market for industrial services in } \\
\text { nascent fields }\end{array}$ & $\begin{array}{l}\text { Journal of } \\
\text { Services } \\
\text { Marketing }\end{array}$ & $* *$ & & $X$ & $X$ & & $\mathrm{X}$ \\
\hline [12] & $\begin{array}{l}\text { Baines \& } \\
\text { W. } \\
\text { Lightfoot }\end{array}$ & 2013 & $\begin{array}{l}\text { Servitization of the manufacturing firm: Exploring } \\
\text { the operations practices and technologies that } \\
\text { deliver advanced services }\end{array}$ & $\begin{array}{l}\text { Int Jrnl of } \\
\text { Op \& Prod } \\
\text { Mnagemnt }\end{array}$ & $* *$ & & & $X$ & X & \\
\hline [20] & $\begin{array}{l}\text { Wünderlich } \\
\text { et al. }\end{array}$ & 2013 & $\begin{array}{l}\text { High Tech and High Touch: A Framework for } \\
\text { Understanding User Attitudes and Behaviors } \\
\text { Related to Smart Interactive Services }\end{array}$ & $\begin{array}{l}\text { Journal of } \\
\text { Service } \\
\text { Research } \\
\end{array}$ & $*$ & & $X$ & & $X$ & $\mathrm{X}$ \\
\hline [39] & $\begin{array}{l}\text { Paluch \& } \\
\text { Wünderlich }\end{array}$ & 2016 & $\begin{array}{l}\text { Contrasting risk perceptions of technology-based } \\
\text { service innovations in inter-organizational settings }\end{array}$ & $\begin{array}{l}\text { Journal of } \\
\text { Business } \\
\text { Research } \\
\end{array}$ & $*$ & & $X$ & $X$ & $X$ & \\
\hline [17] & Raja et al. & 2017 & $\begin{array}{l}\text { Exploring the managerial dilemmas encountered } \\
\text { by advanced analytical equipment providers in } \\
\text { developing service-led growth strategies }\end{array}$ & $\begin{array}{l}\text { International } \\
\text { Journal of } \\
\text { Production } \\
\text { Economics } \\
\end{array}$ & $* *$ & $X$ & $X$ & & $X$ & \\
\hline [40] & $\begin{array}{l}\text { Salonen et } \\
\text { al. }\end{array}$ & 2017 & Servitization as reinforcement, not transformation & JOSM & $*$ & $X$ & $X$ & & $\mathrm{X}$ & \\
\hline [11] & Story et al. & 2017 & $\begin{array}{l}\text { Capabilities for advanced services: A multi-actor } \\
\text { perspective }\end{array}$ & $\begin{array}{l}\text { Industrial } \\
\text { Marketing } \\
\text { Management }\end{array}$ & $* * *$ & $X$ & $X$ & $\mathrm{X}$ & $\mathrm{X}$ & \\
\hline [41] & $\begin{array}{l}\text { Grubic \& } \\
\text { Jennions, } \\
2018\end{array}$ & 2018 & $\begin{array}{l}\text { Remote monitoring technology and servitised } \\
\text { strategies - factors characterising the } \\
\text { organisational application }\end{array}$ & $\begin{array}{l}\text { International } \\
\text { Journal of } \\
\text { Production } \\
\text { Research }\end{array}$ & $*$ & & & $\mathrm{X}$ & $\mathrm{X}$ & $\mathrm{X}$ \\
\hline$[10]$ & $\begin{array}{l}\text { Beverungen } \\
\text { et al., } 2019\end{array}$ & 2019 & Conceptualizing smart service systems & $\begin{array}{l}\text { Electron } \\
\text { Markets }\end{array}$ & $* *$ & & $X$ & & $\mathrm{X}$ & \\
\hline [42] & $\begin{array}{l}\text { Neuhüttler } \\
\text { et al. }\end{array}$ & 2019 & $\begin{array}{l}\text { An Integrative Quality Framework for Developing } \\
\text { Industrial Smart Services }\end{array}$ & $\begin{array}{l}\text { Service } \\
\text { Science }\end{array}$ & * & & $X$ & $\mathrm{X}$ & & \\
\hline [43] & $\begin{array}{l}\text { Romero et } \\
\text { al., } 2019\end{array}$ & 2019 & $\begin{array}{l}\text { The Impact of Digital Technologies on Services } \\
\text { Characteristics: Towards Digital Servitization, }\end{array}$ & $\begin{array}{l}\text { Advances in } \\
\text { Production } \\
\text { Management } \\
\text { Systems }\end{array}$ & $*$ & & & & $\mathrm{X}$ & \\
\hline [35] & $\begin{array}{l}\text { Ruiz-Alba } \\
\text { et al. }\end{array}$ & 2019 & $\begin{array}{l}\text { Servitization strategies from customers' } \\
\text { perspective: the moderating role of co-creation }\end{array}$ & JBIM & $* * *$ & & $\mathrm{X}$ & $\mathrm{X}$ & $X$ & $\mathrm{X}$ \\
\hline$[36]$ & $\begin{array}{l}\text { Vaittinen \& } \\
\text { Martinsuo } \\
\end{array}$ & 2019 & $\begin{array}{l}\text { Industrial customers' organizational readiness for } \\
\text { new advanced services }\end{array}$ & JMTM & $* *$ & X & $X$ & $X$ & X & \\
\hline [44] & Boldosova & 2020 & $\begin{array}{l}\text { Telling stories that sell: The role of storytelling } \\
\text { and big data analytics in smart service sales }\end{array}$ & $\begin{array}{l}\text { Industrial } \\
\text { Marketing } \\
\text { Management }\end{array}$ & $*$ & & & & & $X$ \\
\hline
\end{tabular}




\begin{tabular}{|c|c|c|c|c|c|c|c|c|c|c|}
\hline [6] & $\begin{array}{l}\text { Grandinetti } \\
\text { et al. }\end{array}$ & 2020 & $\begin{array}{l}\text { Fourth industrial revolution, digital servitization } \\
\text { and relationship quality in Italian B2B } \\
\text { manufacturing firms }\end{array}$ & TQM & $*$ & & $\mathrm{X}$ & & & $\mathrm{X}$ \\
\hline [15] & $\begin{array}{l}\text { Kamalaldin } \\
\text { et al. }\end{array}$ & 2020 & $\begin{array}{l}\text { Transforming provider-customer relationships in } \\
\text { digital servitization: A relational view on } \\
\text { digitalization }\end{array}$ & \begin{tabular}{l|} 
Industrial \\
Marketing \\
Management
\end{tabular} & $* * *$ & $\mathrm{X}$ & $\mathrm{X}$ & $\mathrm{X}$ & $\mathrm{X}$ & $\mathrm{X}$ \\
\hline [7] & $\begin{array}{l}\text { Schüritz et } \\
\text { al. }\end{array}$ & 2020 & $\begin{array}{l}\text { Value Co-Creation in Data-Driven Services: } \\
\text { Towards a Deeper Understanding of the Joint } \\
\text { Sphere }\end{array}$ & ICIS & ** & & $\mathrm{X}$ & & $\mathrm{X}$ & \\
\hline [45] & Shah et al. & 2020 & $\begin{array}{l}\text { Servitization and supply chain integration: An } \\
\text { empirical analysis }\end{array}$ & $\begin{array}{l}\text { International } \\
\text { Journal of } \\
\text { Production } \\
\text { Economics } \\
\end{array}$ & * & & $\mathrm{X}$ & $\mathrm{X}$ & $\mathrm{X}$ & \\
\hline [1] & Sjödin et al. & 2020 & $\begin{array}{l}\text { An agile co-creation process for digital } \\
\text { servitization: A micro-service innovation approach }\end{array}$ & $\begin{array}{l}\text { Journal of } \\
\text { Business } \\
\text { Research }\end{array}$ & $* * *$ & $\mathrm{X}$ & $\mathrm{X}$ & $\mathrm{X}$ & $\mathrm{X}$ & $\mathrm{X}$ \\
\hline [16] & Linde et al. & 2021 & $\begin{array}{l}\text { Revenue Models for Digital Servitization: A Value } \\
\text { Capture Framework for Designing, Developing, } \\
\text { and Scaling Digital Services }\end{array}$ & IEEE Trans & ** & & $\mathrm{X}$ & & $\mathrm{X}$ & $\mathrm{X}$ \\
\hline & & & & & $\sum$ & 6 & 17 & 11 & 16 & 9 \\
\hline
\end{tabular}

